\title{
HIGIENOS DISCIPLINOS DE்STYMAS VILNIAUS STEPONO BATORO IR KAUNO VYTAUTO DIDŽIOJO UNIVERSITETUOSE 1919-1939 METAIS
}

\author{
Aistis Žalnora \\ Vilniaus universiteto Medicinos fakulteto Sveikatos mokslu institutas
}

Raktažodžiai: higiena, disciplina, dèstymas, Vilnius, Stepono Batoro universitetas, Kaunas, Vytauto Didžiojo universitetas, Jonas Šliūpas, Jonas Šopauskas.

\section{Santrauka \\ Tyrime palygintas higienos mokymas dviejuose tarpukario laikotarpio universitetuose. Stepono Batoro universitetas veikè Vilniuje (1919-1939 m.), o Vytauto Didžiojo uni- versitetas, anksčiau vadintas Lietuvos universitetu, Kaune. Mūsų tyrimas atskleidè higienos disciplinos dėstymo skir- tumus Vilniaus ir Kauno universitetuose. Darbe pateikti duomenys liudija, jog šiuos skirtumus lèmé skirtingų te- orinių higienos tyrimų ir dèstymo modelių pasirinkimas. Stepono Batoro universiteto Higienos katedra prioritetine tyrimų sritimi pasirinko socialinę higieną, todèl ir Vil- niuje dèstomose programose jau 3 dešimtmetyje buvo na- grinejamos sveikatos apsaugos sistemos organizavimo ir kitos socialinès higienos laukui būdingos problemos. Vy- tauto Didžiojo universiteto Medicinos fakulteto Higienos ir bakteriologijos katedroje socialinès higienos idèjos im- tos nagrinèti tik 4 dešimtmečio pabaigoje, o dèstymo pro- gramose kaip atskiras objektas šie klausimai neatsispindi. Vis dèlto mūsų tyrime nustatème, jog pirmieji pažangūs bandymai nagrinèti socialinès higienos problemas Lietu- voje sietini su gydytojo ir visuomenininko Jono Šliūpo (1861-1944) veikla.}

\section{Ivadas}

Vienas iš svarbiausių XX a. pradžios sveikatos mokslų raidos lūžių buvo higienos mokslo, kaip savarankiškos mokslo šakos, susiformavimas. Ypač svarbi buvo socialinè higiena, atkreipusi visuomenès ir medikų dèmesị ị itin kompleksišką socialinę ligų kilmę. Nors gydytojų higienistų to meto universitetai dar neruošè, tačiau jų medicinos studijų programose dèmesys higienos problemoms didejo. Ši tematika, iš dalies nagrinèta ankstesniuose darbuose, neaprépia to meto medicinos ir higienos programų turinio lyginamosios analizės.
Darbo tikslas - palyginti higienos disciplinos dèstymą Vilniaus Stepono Batoro universitete ir Lietuvos, vèliau Vytauto Didžiojo, universitete Kaune, 1919-1939 metais.

\section{Tyrimo medžiaga ir metodai}

Lyginamiesiems Stepono Batoro universiteto ir Vytauto Didžiojo universiteto tyrimams nagrinètos to meto publikacijos, studijų programos ir kiti prieinami šaltiniai bei literatūra. Taikytas lyginamosios analizès metodas.

\section{Tyrimo rezultatai}

Po Vilniaus krašto aneksijos $1919 \mathrm{~m}$. Vilniuje buvo ịkurtas Stepono Batoro universitetas (SBU). Universitete buvo 6 fakultetai: humanitarinių mokslų, teologijos, teisès ir socialinių mokslų, matematikos ir gamtos mokslų, medicinos [1]. Kaune panašios struktūros universitetas atidarytas $1922 \mathrm{~m}$. ir pavadintas Lietuvos universitetu, nuo $1930 \mathrm{~m}$. vadinamas Vytauto Didžiojo universitetu (VDU). Jame taip pat buvo šeši fakultetai: teologijos-filosofijos, humanitarinių mokslų, teisès, matematikos ir gamtos mokslų, technikos ir medicinos. Savo dydžiu ir pajègumas abu universitetai buvo panašūs. VDU per aptariamaji laikotarpi baigè 3790, SBU - 4255 absolventų [2].

Vilniaus SBU medicinos fakultetą sudare 27 katedros, klinikos ir kiti padaliniai. Pirmaisiais mokslo metais medicinos fakultete studijas pradèjo 115 studentų. $1919-1939 \mathrm{~m}$. į medicinos studijas kasmet buvo priimama vidutiniškai 120 pirmakursių [3]. 1924-1938 m. 1300 absolventų gavo medicinos diplomus [4]. VDU medicinos fakultetas Kaune savo dydžiu ir struktūra, absolventų skaičiumi taip pat buvo panašus. Jị sudare 4 skyriai: veterinarijos, farmacijos, odontologijos ir medicinos. Medicinos skyrių (fakultetą) sudare 26 katedros ir klinikos [5]. $1922 \mathrm{~m}$. VDU medicinos fakultete studijavo 190 studentų, 114 iš jų pasirinko medicinos studijas. 1922-1940 metais Medicinos fakultetą baige 1223 studentai [2].

Šiuo laikotarpiu higiena kaip mokslinè disciplina dar tik formavosi, ją dèstanti profesūra formaliai nebuvo baigusi higi- 
enos kaip savarankiškos specialybės. Higieną dėstė gydytojai, turintys daugiausia klinikinès patirties, vèliau nusprendę specializuotis higienos srityje. Tai iliustruoja Vilniaus higienistu pavyzdys. Kazimieras Karafa-Korbutas (Karaffa-Korbutt, 1878-1935) baigė mediciną Sankt Peterburgo karo medicinos akademijoje. Nuo $1909 \mathrm{~m}$. jis dirbo šios akademijos higienos skyriuje. 1913-1914 m. stažavosi Berlyno vandens higienos institute ir Pastero institute Paryžiuje. 1914 m. jis gavo docento laipsnį Sankt Peterburgo medicinos akademijoje [6]. Aleksandras Safarevičius (Safarewicz, 1876-1936) studijavo mediciną Kijevo universitete, kurị baigè 1903 metais. Keletą metu dirbo savivaldybès pirmosios medicinos pagalbos stotyje, vadinamojoje Pastero stotyje Vilniuje, o nuo 1908-1910 $\mathrm{m}$. - Sankt Peterburgo eksperimentinès medicinos institute ir Varšuvos bakteriologijos laboratorijoje [7].

Panašų išsilavinimą igijo ir Kauno higienistai, iš pradžių labiau žinių sėmęsi Rytų Europos universitetuose. Pirmasis Kauno higienos ir bakteriologijos katedros vedejjas Antanas Jurgeliūnas (1872-1943), kaip ir K. Karafa-Korbutas bei Aleksandras Safarevičius, studijavo mediciną Rusijoje ir Ukrainoje. 1896 m. A. Jurgeliūnas baigè Sankt Peterburgo fizikos ir matematikos fakultetą, o 1900 m. medicinos fakultetą Kijevo universitete. Jis dirbo Kijevo ir Maskvos universitetų bakteriologijos katedroje [5]. Jonas Šopauskas (1900-1968) buvo VDU MF absolventas, 1934-1935 m. stažavosi Paryžiuje ir Stokholme [8]. Šios aplinkybès, galimai kartu su teigiama profesoriaus Vlado Lašo (1892-1966) įtaka [9], 4 dešimtmetyje pastūmèjo higienos katedros mokslinès minties raidą socialine linkme.

Tarpukario laikotarpis Europos istorijoje išskiriamas kaip laikas, kai buvo suvokta, kad medicina, pagrịsta vien gydymu, negali išspręsti visų visuomenès sveikatos problemų. Svarbiausia to meto sveikatos apsaugos sistemos užduotimi tapo socialinių ligų priežasčių paieškos, formavosi socialinès higienos disciplinos [10]. Šiuo laikotarpiu atliktos institucinès reformos, padejjusios plètoti socialinès higienos mokslą. Senasis modelis, kai higiena laikyta pagalbine bakteriologijos disciplina, buvo sukritikuotas Vakarų Europos universitetuose -Vokietijoje, Prancūzijoje ir kitose Europos šalyse, ịskaitant Lenkiją. Lenkų mokslininkai Ludvickas Fleckas (Fleck, 18961961) ir Adamas Vžosekas (Wrzosek, 1888-1968) manè, kad bakteriologija ir higiena yra du skirtingi mokslai, turintys skirtingus tikslus, todẻl jie turètų būti studijuojami skirtinguose padaliniuose. Priešingu atveju vienas profesorius negalètų deramai aptarti abiejų dalykų [11].

Apie tokių idèjų buvimą Lietuvoje bent jau 3 dešimtmetyje duomenų neturime, o VDU MF institucinès higienos katedros ir SBU MF higienos katedros formalios struktūros skirtumai rodo jog Kaune de facto buvo vadovaujamasi skirtingais modeliais. Jau iš pat pradžių $1922 \mathrm{~m}$. Vilniuje buvo ịsteigta autonomiška higienos katedra, atskira nuo bakteriologijos katedros [10]. VDU MF higienos katedra visu aptariamuoju laikotarpiu buvo sujungta su bakteriologijos katedra ir tik $1939 \mathrm{~m}$. buvo įsteigtos dvi atskiros katedros [5].

Prielaidas medicinos ir higienos disciplinų dėstymo skirtumams atskleidžia ir skirtingi dėstymo programų pasirinkimai Vilniuje ir Kaune. Kauno Vytauto Didžiojo universiteto programos buvo sukurtos pasirinkus kompromisą tarp teorinių rusų ir vokiečių modelių dalykų ir praktinio angliško modelio klinikinėms disciplinoms [2]. Vilniuje dèstomos programos buvo sukurtos pavyzdžiu pasirinkus JAV, Prancūzijos ir Vokietijos modelius [11].

Tarpukario Vilniuje ir Kaune higienos disciplinos buvo dėstomos kartu su bendrosiomis medicinos disciplinomis, todèl toliau tyrime nagrinèjome medicinos studijų programas. Medicinos programų struktūra ir įgyvendinimo būdas Vilniuje ir Kaune skyrèsi, tačiau būta ir panašumų. Vilniuje buvo trimestrų sistema. Studijos truko 16 trimestrų [12]. VDU buvo pažangesnè semestrų sistema. Studijos truko 10 semestrų [13]. Abiejose programose buvo dèstomos tokios bazinès disciplinos kaip patologinė anatomija, histologija, chirurgija, vidaus ligos, ginekologija, pediatrija, dermatologija, bakteriologija, oftalmologija, otolaringologija ir kt. [5] [12].

Literatūroje teigiama, kad medicinos studijos Vilniuje buvo sudetingos, orientuotos ì plataus profilio gydytojo išsilavinimą. [14]. Tai patvirtina ir mūsų atlikta programų analizè. Vilniuje, kitaip nei Kaune, vidaus ligų ir chirurgijos kursai buvo labai platūs, apėmé skirtingą problematiką, teorija, kartu su praktika, sudare 800 valandų [15]. Vilniuje dėstomi kursai buvo išsamesni, Kaune - bendresni. Buvo gana daug dalykų, kurie tik Vilniuje buvo studijuojami kaip savarankiški, pavyzdžiui: fizika, biologija, citologija, antropologija, rentgenologija, odos tuberkuliozè, pirmoji pagalba sergant otolaringologinemis ligomis, gydytojo etika [12] [13].

Vilniuje higienos disciplinos buvo dèstomos 5 kurse, joms per savaitę buvo skirta 4 valandos teorijos paskaitų, per metus 80 valandu teorijai ir 20 valandų pratyboms. Pavasario trimestrą buvo 5 valandos pratybų per savaitę. Nuo 1924 m. pratybų skaičius didejjo, jos truko visus metus [15]. Kaune higienos disciplinos buvo dèstomos 4 kurse, rudens ir pavasario semestruose. Joms skirta 2 valandos teorijos ir 4 valandos pratybu [5]. Vilniuje higienos kursas truko ilgiau, tačiau abiejuose universitetuose higienos kursas buvo gana trumpas. Palyginimui tuo metu JAV higienos kursas truko 160 valandų, Sovietų Rusijoje net 700 valandų, o Berne (Šveicarija) higienos dalykai buvo dėstomi net 5 metus [17].

Remdamiesi turimais duomenimis, galime teigti, kad abiejuose universitetuose higienos klausimams buvo skiriama per mažai dèmesio $[13,15]$. Laipsniškai imama suvokti higienos mokslo svarba, kurią patvirtina vèlyvosiose J. Šopausko publikacijose išreikštos mintys. $1938 \mathrm{~m}$. paskelbtame straipsnyje 
„Higienos uždaviniai šių dienų gyvenime“, profesorius teigè, jog ,ateityje gydytojų gali visai nebereiketi, nes higienistai gali išspręsti visas iškilusias sveikatos problemas $<$.. $>$ jei tai ir neįvyktų, tai jau dabar labai aišku, kad kiekvienas gydytojas turi būti ir higienistas tuo pačiu metu" [18]. Ši mintis beveik identiška kito Vilniaus higienisto Brunono Novakovskio (Nowakowski, 1890-1966) idejai: „, Kiekvienas gydytojas taps geru gydytoju tik tada, kai supras abipusi gydymo ir higienos ryšị “ [19].

Verta panagrinèti ir palyginti, kokie moksliniai klausimai buvo nagrinėjami paskaitų metu SBU MF ir VDU MF higienos katedrose. SBU MF higienos kursas apėmé šiuos aspektus: 1) statistikos pagrindai, 2) maisto higiena ir mityba, 3) šilumos reguliavimas kūne, 4) būstas ir aplinka, 5) darbo higiena ir ergonomika, 6) užkrečiamujų ligų prevencija, 7) socialinė higiena, 8) eugenika ir rasės higiena, 9) sveikatos apsaugos ir sveikatos teisès aktų organizavimas [16], VDU MF higienos programa apėmé šiuos aspektus: 1) aplinkos ir patalpų higiena, 2) drabužių higiena, 3) maisto higiena, 4) kova su infekcinėmis ligomis, 5) kova su venerinemis ligomis ir tuberkulioze, 6) mokyklų higiena 7) kalèjimų, kareivinių ir ligoninių higiena, 8) darbo medicina, 9) sanitariné statistika, duomenų rinkimas ir analizé, 10) rasinè higiena [20]. Programos buvo panašios, tačiau programa Kaune neapėmė socialinès higienos ir sveikatos teisès aktu ir sveikatos priežiūros organizavimo temų, kaip savarankiškų aspektų.

Dar vienas svarbus mūsų tyrimo klausimas buvo to meto higienos vadovèliai. 1922 m., kai K. Karafa-Korbutas pradèjo mokyti higienos, universitetiniam kursui skirto higienos vadovèlio lenkų kalba dar nebuvo sukurta, todèl profesorius nusprendè pats parašyti pirmajị higienos vadovèlị universitetiniam kursui. 1924 m. Anglijoje ir kitose Vakarų šalyse surinktus duomenis profesorius susistemino ị pirmaji „Higienos užrašųu“ (lenk. Zarys higieny) tomą [21]. Vèlesniais metais buvo išleisti dar keli originalūs vadovèliai. $1925 \mathrm{~m}$. K. Karafa-Korbutas ir Vitoldas Gondzikievičius (Gądzikiewicz, 1879-1962) išleido studentų higienos praktikos darbų vadovą [17]. Praktikų metu studentai buvo ịpareigojami rengti viešas paskaitas Vilniaus miesto gyventojams, rašyti individualius mokslo tiriamuosius darbus [16]. 1926 m. A. Safarevičius ir K. Karafa-Korbutas parenge dar vieną vadovèlį studentams "Zadanie sanitarne“ [22]. 1934 m. K. Karafa-Korbut ir A. Safarewicz, papildydami ankstesnius duomenis, parengè papildytą higienos vadovèli universitetams [23]. Socialinès higienos klausimai aptariami trijuose iš keturių minètų vadovèlių.

$1935 \mathrm{~m}$. VDU MF higienos ir bakteriologijos katedra parengè vadovèlį studentams „Higienos praktikos darbai“ [24]. Tai buvo pirmasis universiteto higienos praktikos vadovèlis lietuvių kalba, kuriame išsamiai aprašyti praktiniai pieno, vandens, maisto, pastatų ir kt. tyrimų metodai [9]. Mūsų tyrimo metu pavyko rasti vadovèlį, kuris turètų būti laikomas pirmuoju lietuvišku higienos teorijos vadovėliu, apimančiu ne tik fizinès bet ir socialinès higienos klausimus. Tai nepelnytai pamirštas gydytojo ir visuomenès veikejjo Jono Šliūpo (18611944) 1828 m. išleistas vadovèlis „Higièna arba sveikatos dèsnių mokslas" [25].

K. Karafa-Korbuto „Zarys Hygieny“ ir J. Šliūpo „Higièna arba sveikatos dèsnių mokslas" vadovèlių struktūrinè analizė parodè, kad abu autoriai nagrinèjo panašias temas, kaip antai: asmeninè higiena; sveika mityba ir maisto tikrinimo pagrindai; profesinė sveikata; fizinė aplinka: oras, vanduo, dirvožemis; higieniškas būstas; mokyklų higiena; kova su infekcinemis ligomis; socialinè higiena ir eugenika, bei kt. K. KaraffaKorbuto vadovélyje buvo aptartas platesnis epidemiologinių klausimų, tokių kaip sanitarinès statistikos metodai; natūrali gyventojų dinamika ir statistika, susijusi su sveikatos politika ir prevencinių mechanizmų organizavimu, spektras. Tikètina, kad J. Šliūpas savo darbe net neketino aptarti minètų klausimų, nes vadovèlis buvo skirtas labiau visuomenès švietimui. Remdamiesi turimais duomenimis galime teigti, kad daugelis socialinės higienos klausimų, aptartų J. Šliūpo darbe, iki 4 dešimtmečio pabaigos VDU MF higienos ir bakteriologijos katedroje nebuvo nagrinejjami. Darome išvadą, kad J. Šliūpą turètume laikyti socialinès higienos idèjų pradininku Lietuvoje.

Nors turime duomenų, jog J. Šliūpas dėstė VDU MF [26], tačiau higienos kurso VDU MF higienos ir bakteriologijos katedroje déstyti jam neteko [27]. Galbūt todèl pastarojo meto progresyvios socialinès higienos idejos VDU MF higienos kurso programoje neatsispindejo, o minèta katedra iki 4 dešimtmečio buvo susitelkusi ị bakteriologijos srities problematiką - kovą su infekcinėmis ligomis, kuri buvo pagrindinis senojo modelio bruožas.

Naujasis socialinis higienos modelis taip pat turejo trūkumų. Lenkijos universitetų higienos programa nepakankamai supažindindavo studentus su infekcinių ligų problemomis. Infekcinių ligų klausimai buvo pristatomi tik vidaus ligų kursuose, todèl medicinos fakulteto absolventai apie infekcines ligas ir jų prevencijos priemones sužinodavo tik dirbdami ligoninèse [16].

\section{Išvados}

1. Higienos mokslo ir didaktikos raida Vilniuje ir Kaune susikloste skirtingai.

2. Vilniaus Stepono Batoro universiteto higienos katedra prioritetine tyrimų kryptimi pasirinko socialinę higieną.

3. Kauno Vytauto Didžiojo universiteto higienistų modelyje pagrindinis tyrimų akcentas - kova su infekcinemis ligomis.

4. SBU desstytame kurse nuo 3 dešimtmečio jau buvo aptariamos socialinės higienos problemos, analogiškose VDU programose šios problemos kaip atskiras objektas nagrinejjamos nebuvo. 


\section{Literatūra}

1. Tylińska E. The revival of the Vilnius university in 1919: historical conditions and importance for Polish science. The global and the local: the history of science and the cultural integration of Europe. Proceedings of the 2th ICESHS (Crakow) 2006: 898-899.

2. Boruta J., Bumblauskas A. Alma Mater Vilnensis: Vilniaus universiteto istorijos bruožai. Vilnius, 2012:712-723; 677-680; $723 ; 729$.

3. Lietuvos centrinis valstybès archyvas. f. 175, ap. 3 IXB, b. 254 ; ap. 3IXCa, b.149-171.

4. Brożek K. Wydział Lekarski uniwersytetu Stefana Batorego w Wilnie. Annales Academia Medicinae Silesiensis (Katowice) 1999; 38-39: 115-126.

5. Meškauskas J., Medicinos fakultetas. Lietuvos universitetas

(Chicago) 1972:492-493; 182-183; 114.

6. Safarewicz AŚ. Profesor Dr. Med. Kazimierz-Wacław KaraffaKorbutt. Pamiętnik Wileńskiego Towarzystwa Lekarskiego (Wilno) 1934; 10(2-3):8-11.

7. Bortkiewicz-Rodzewiczowa J. Prof. Aleksander Safarewicz. Wspomnienie pośmiertne. Medycyna (Warszawa) 1936; 2-3: 666-668.

8. Visuotinė lietuvių enciklopedija. Jonas Šopauskas. https://www. vle.lt/straipsnis/jonas-sopauskas/

9. Obelenis V. Higienos raida Kauno aukštojoje medicinos mokykloje. Higienos mokslui Lietuvoje 190 metų. Vilnius, 1997: 58-61.

10. Žalnora A. The role of the Hygiene Department of Stephen Bathory University in the development and promotion of public health in Vilnius in the years 1922-1939. Studia Historiae Scientiarum. Warszawa, 2018; 17: 51-87. https://doi.org/10.4467/2543702XSHS.18.004.9324

11. Jaszke M, Jaszke J. Problematyka higieniczna w polskich ośrodkach akademickich okresu międzywojennego (19191939). Archiwum Historii i Filozofii Medycyny: Szczecin, 1997; 60(4): 327-334.

12. Lietuvos centrinis valstybès archyvas. f. 175 ap. 3IXD b. 1426 1. 42-56.

13. Vytauto Didžiojo universiteto antrųų penkerių metų apyskaita. (Kaunas) 1933: 276.

14. Čibiras P. Mano kelias į mokslą ir Medicinos praktiką. Vilniaus medicinos istorijos almanachas [red. A. Andriušis]. Vilnius, 1997; 1: 273-308.

15. Lietuvos centrinis valstybės archyvas. f. 175 ap. 3IB. b. 19 L. 63-66.

16. Karaffa-Korbutt K, Safarewicz A. Pierwsze dziesięciolecie dziełalności Zakładu Higieny USB. Kazimierz-Wacław Karaffa-Korbutt. Pamiętnik Wileńskiego Towarzystwa Lekarskiego: Wilno, 1933; 9(5): 488-507.

17. Sztuka-Polińska U. Kadry i ich szkolenie na potrzeby zwalczania chorób zakaźnych w okresie międzywojennym w Polsce. Przegląd Epidemiologiczny: Warszawa, 2000; 54: 427-434.
18. Šopauskas J. Higienos uždaviniai šių dienų gyvenime. Kaunas: Medicina, 1938; 2: 105-116.

19. Nowakowski B. Społeczna rola higieny. Pamiętnik Wileńskiego towarzystwa lekarskiego. Wilno, 1937; 13(1): 234-245.

20. Vytuto Didžiojo universiteto Medicinos skyriaus programos. Kaunas, 1933:120.

21. Karaffa-Korbutt K. Zarys higjeny. Wilno, 1924.

22. Karaffa-Korbutt K, Safarewicz A. Zadanie sanitarne. Wilno, 1926.

23. Karaffa-Korbutt K. Higjeja kurs uniwersytecki. Wilno, 1934.

24. Jurgeliūnas, A. Higienos praktikos darbai. Kaunas, 1935.

25. Šliūpas J. Higièna arba sveikatos dèsnių mokslas. Šiauliai, 1928.

26. Petrauskienė J., Kalėdienė R. Lignugarienė A. Medicinos istorijos dèstymas Kauno aukštojoje medicinos mokykloje. Lietuvos Sveikatos mokslų universiteto Medicinos akademijos Sveikatos vadybos katedros raida (1951-2011). Kaunas, 2012.

27. Janušonis V. Dr. Jono Šliūpo darbai sveikatos apsaugos organizavimo ir valdymo Lietuvos Respublikoje kontekste. Aušrininkas Dr. Jonas Šliūpas Lietuvos medicinos baruose. Klaipèda, 1995;19.

\section{TEACHING OF HYGIENE DISCIPLINE IN VILNIUS STEPHEN BATHORY AND KAUNAS VYTAUTAS MAGNUS UNIVERSITIES IN 1919-1939 \\ A. Žalnora}

Keywords: hygiene, discipline, teaching, Vilnius, Stephen Bathory University, Kaunas, Vytautas Magnus University, Jonas Šliūpas, Jonas Šopauskas.

\section{Summary}

In our study, we compared hygiene teaching at two interwar universities. One of them, Stephen Bathory University, operated in Vilnius in 1919-1939. Another, Lithuanian, later Vytautas Magnus University, operated in Kaunas. Our research revealed differences in the teaching hygiene subject in Vilnius and Kaunas universities. The data presented in our study testify that the these differences were determined by the choices of different theoretical hygiene research and teaching model. The Department of Hygiene of Vilnius Stephen Bathory University has chosen social hygiene as a priority research area, therefore the hygiene teaching programs taught in Vilnius have been dealing with the organization of the health care system and other problems specific to the field of social hygiene already in early 1920s. The ideas of social hygiene were examined at the Department of Hygiene and Bacteriology of the Faculty of Medicine of Kaunas Vytautas Magnus University only at the end of the 1930s. However, teaching curricula do not reflect these issues as a separate study object. Nevertheless, our study reveals that the first progresive attempts to examine the problems of social hygiene in Lithuania are related to the activities of the doctor and public figure Jonas Šliūpas (1961-1944).

Correspondence to: aistis.zalnora@mf.vu.lt

Gauta 2021-03-05 